\title{
SIFAT FISIKO-KIMIA SEMI REFINED CARRAGEENAN DARI KOTA AMBON DAN KABUPATEN MALUKU TENGGARA BARAT
}

\author{
Raja Bonan Dolok Sormin ${ }^{1}$, Dwight Soukotta ${ }^{1}$, Saiful $^{1}$, Agustina Risambessy ${ }^{2}$, Stenly \\ Jacobus Ferdinandus ${ }^{2}$ \\ ${ }^{1}$ Fakultas Perikanan dan Ilmu Kelautan Universitas Pattimura Ambon \\ ${ }^{2}$ Fakultas Ekonomi dan Bisnis Universitas Pattimura Ambon \\ Universitas Pattimura, Jalan Mr. Chr. Soplanit Kampus Poka-Ambon 97233 Maluku \\ Telepon 0911 3825060; Fax. 0911-3825061 \\ *Korespondensi: rbd.sormin@yahoo.com \\ Diterima: 11 Agustus 2017/ Disetujui: 12 April 2018
}

Cara sitasi: Sormin RBD, Soukotta D, Saiful, Risambessy A, Ferdinandus SJ. 2018. Sifat fisiko-kimia semi refined carrageenan dari Kota Ambon dan Kabupaten Maluku Tenggara Barat. Jurnal Pengolahan Hasil Perikanan Indonesia. 21(1): 92-98.

\begin{abstract}
Abstrak
Rumput laut (seaweed) atau alga merupakan bagian terbesar dari tanaman laut dan komoditi ekspor yang potensial untuk dikembangkan. Indonesia memiliki lima jenis rumput laut yang bernilai ekonomis tinggi sebagai komoditi ekspor dan juga dikonsumsi domestik yaitu Eucheuma sp., Glacillaria sp., Gelidium sp., Sargassum sp. dan Hypnea sp. E. cottoni dan E. spinosum merupakan spesies alga merah penghasil karaginan dan andalan eksport Indonesia. Rumput laut jenis ini banyak dibudidayakan di Propinsi Maluku khususnya di Kota Ambon dan Kabupaten Maluku Tenggara Barat. Tujuan dari penelitian ini adalah menentukan sifat fisiko-kimia semi refined carrageenan (SRC) E. cottonii yang berasal dari desa Waiheru, Kota Ambon dan Desa Lermatang, Kabupaten Maluku Tenggara Barat. Metode penelitian adalah deskriptif. Analisis meliputi perhitungan rendemen, fiskositas, kekutan gel, kadar air, abu dan sulfat. Hasil pengamatan sifat fisiko-kimia SRC dari desa Lermatang Kabupaten Maluku Tenggara Barat rendemen yaitu 26,8\%, fiskositas 60,80 cP, kekutan gel $100 \mathrm{~g} / \mathrm{cm}^{2}$, kadar air 15,79\%, abu 21,24\%, dan sulfat 13,27\%, dan SRC dari desa Waiheru Kota Ambon dengan rendemen 24,73\%, fiskositas 121,60 cP, kekuatan gel $700 \mathrm{~g} / \mathrm{cm}^{2}$, kadar air 16,04\%, abu 15,26\%, dan sulfat 12,34\%.
\end{abstract}

Kata Kunci: Eucheuma cottonii, kadar sulfat, karaginan, kekuatan gel, sulfat

\section{Physico-chemical Charachteristic of Semi Refined Carrageenan from Ambon City and Southwest Maluku District}

\begin{abstract}
Seaweeds (algae), the largest part of marine plants are a potential export commodities to be developed. In Indonesia there are five types of seaweed that has high economic value as an export commodity and also consumed domestically i.e. Eucheuma sp, Glacillaria sp, Gelidium sp, Sargassum sp, and Hypnea sp. E. cottoni and E. spinosum, the species of red algae produced carrageenan are the Indonesia's leading exports. In Maluku Province this seaweeds is widely cultivated especially in Ambon City and West Southeast Maluku Regency. The purpose of this research is to determine the physico-chemical properties of semi refined carrageenan (SRC) of seaweed E. cottonii originating from Waiheru village, Ambon City and Lermatang Village, Southeast Maluku Regency. The research method was descriptive by observing rendement, viscosity, gel strengt, water content, ash content and sulfate content. The result showed, the physico-chemical properties of SRC originated from Lermatang village of West Southeast Maluku Regency based on, viscosity, gel strength, moisture content, ash content and sulphate content were $26.8 \%, 60.80 \mathrm{cP}, 100 \mathrm{~g} / \mathrm{cm}^{2}, 15.79 \%$, $21.24 \%$, and $13.27 \%$ respectively, while that of Waiheru village, Ambon City were $24.73 \%, 121.60 \mathrm{cP}, 700 \mathrm{~g} /$ $\mathrm{cm}^{2}, 16.04 \%, 15.26 \%$ and $12.34 \%$ respectively.
\end{abstract}

Key words: carrageenan, Eucheuma cottonii, gel stength, seaweeds, sulfit content 


\section{PENDAHULUAN}

Karaginan adalah sebutan untuk polisakkarida linier sulfat dari D-galactose dan 3,6-anhydro-D-galactose yang diekstrak dari berbagai spesies rumput laut/ alga merah (Rhodophyceae) contohnya: Gigartina, Chondruscrispus, Eucheuma dan Hypnea. Karaginan secara luas digunakan dalam industri pangan karena sifat fisik dan fungsionalnya, misalnya pengental, pembentuk gel, dan kemampuan stabilisasi, suspensi protein, juga dalam bidang industri farmasi sebagai bahan pembungkus pil/tablet, kosmetik, percetakan dan industri tekstil (Campo et al. 2009; Bono et al. 2011).

Karaginan lebih dari empat dekade telah menjadi bahan industri yang penting. Negaranegara di Asia tenggara telah memproduksi 96,5\% dari total produksi karaginan yang diekstrak dari alga merah. Filippina berkontribusi 55\% diikuti oleh Indonesia 38\% dan Malaysia 2,5\% (Bindu dan Levine 2010).

Semi refined carrageenan (SRC) jauh lebih mudah dan murah diproduksi sebagai hidrofilik polisakkarida alami dalam pangan dan produk non pangan. SRC diterima sebagai karaginan dan tidak mempunyai perbedaan secara legalitas (FDA 2017), sementara peraturan Uni Eropa (EU) ada perbedaan antara SRC dan refined karaginan yaitu SRC diberi ijin dengan kode E407a dengan nama Processed Eucheuma Seaweeds (PES) atau Philiphine Natural Grade (PNG) serta karaginan diberi kode E407. Jenis karaginan ditentukan berdasarkan tingkat selulosa sisa. Selulosa pada karaginan hampir semua sudah dipisahkan dengan cara penyaringan selama proses,sedangkan SRC masih mengandung selulosa pada larutan karaginan alaminya. Karaginan menunjukkan larutan yang jernih, sedangkan SRC larutannya keruh.

Wenno et al. (2012) mengemukakan bahwa Maluku merupakan salah satu sentra produksi rumput laut. Kabupaten Maluku Tenggara Barat dan Kota Ambon adalah dua kabupaten yang banyak membudidayakan rumput laut tersebut. Hasil wawancara dengan petani rumput laut bahwa produksi rumput laut kering perminggu bisa mencapai 8-12 ton yang merupakan pendapatan masyarakat setempat, namun masalah yang dihadapi oleh para petani rumput laut, hanya dapat memproduksi rumput laut kering yang harganya relatif rendah yaitu Rp. 6.000-7.000/ $\mathrm{kg}$, sedangkan apabila diolah lebih lanjut menjadi SCR, maka harga ini dapat meningkat menjadi sepuluh kali lipat.

Penelitian tentang rumput laut sudah banyak dilakukan. Mustapha et al. (2011) menganalisis pengaruh dari suhu, konsentrasi alkali dan jenis bahan pengekstrak yang digunakan untuk produksi kappa karaginan dari Eucheuma cotonii, serta mempelajari karakteristik fisiko-kimia dan pembentukan gel SRC. Dewi et al. (2012) juga meneliti kualitas SRC yang berasal dari perairan yang berbeda. SRC dari E. cottonii dan Kappaphycus alvarezii dari perairan yang berbedamempunyaikualitasyangberbedapula. Yong et al. (2014) menganalisis pengaruh metode budidaya terhadap kualitas SRC metode yang digunakan adalah budidaya kultur jaringan dan budidaya di alam. Dewi et al. (2015) meneliti pengaruh metode pengeringan terhadap kualitas dan sifat struktur morfologis SRC K. alvarezii.

Mutu dari SRC dapat dipengaruhi oleh banyak hal, maka penelitian ini difokuskan pada studi pengaruh lokasi budidaya rumput laut terhadap mutu SRC yang dihasilkan. Lokasi budidaya rumput laut yang dipilih adalah Desa Waiheru, Kota Ambon dan Desa Lermatang Kabupaten Maluku Tenggara Barat. Tujuan dari penelitian ini adalah menentukan sifat fisiko-kimia semi refining carrageenan (SRC) E. cottonii yang berasal dari desa Waiheru, Kota Ambon dan Desa Lermatang, Kabupaten Maluku Tenggara Barat.

\section{BAHAN DAN METODE Bahan dan Alat}

Bahan yang digunakan dalam penelitian ini terdiri dari rumput laut kering jenis E. cottonii (berasal dari Desa Waiheru, Kota Ambon dan Desa Lermatang Kabupaten Maluku Tenggara Barat, kapur $\mathrm{CaCO}_{3}, \mathrm{KOH}$ teknis dan air bersih. Alat yang digunakan adalah: panci stainless steel, thermocopel (Constant), kompor (HOCK), pH-meter (Hanna)dan alat pengering. 


\section{Metode Penelitian}

Penelitian ini merupakan penelitian deskriptif, dengan mengamati sifat fisiko kimia semi refined carrageenan (SRC) dari dua lokasi yang berbeda yaitu dari Desa Waiheru di Kota Ambon dan Desa Lermatang di Kabupaten Maluku Tenggara Barat. Sifat fisiko kimia terdiri dari: rendemen, kekuatan gel, viskositas, kadar air, kadar abu dan kadar sulfat. Data dari setiap parameter diulang 4 kali, kemudian dirata-ratakan.

\section{Pembuatan SRC}

Rumput laut kering dicuci, kemudian direndam dalam larutan $\mathrm{CaCO}_{3} 2 \%$ selama satu malam untuk menghilangkan garamgaram dan bau. Rumput laut tersebut kemudian direbus dalam larutan $\mathrm{KOH}$ 0,5\% dengan perbandingan rumput laut kering dan larutan 1:10 (w/v) pada suhu $75^{\circ} \mathrm{C} \pm 2^{\circ} \mathrm{C}$ selama 30 menit. Rumput laut dicuci dengan air bersih sampai pH netral (sekitar 7), hasil cucian dinamakan SRC. SRC yang masih basah ditiriskan, dipotong-potong dengan panjang sekitar 1-2 cm dan dikeringkan dibawah sinar matahari, perlakuan diulang empat kali.

\section{Analisis fisiko-kimia}

Rendemen

Rendemen SRC sebagai hasil ekstraksi dihitung berdasarkan rasio antara berat SRC yang dihasilkan dengan berat rumput laut kering yang digunakan, pengukuran rendemen mengacu pada FMC Corp (1977)

Rendemen $=\frac{\text { Berat SRC Kering }}{\text { Berat Rumput Laut Kering }}$

Kadar Air

Penentuan kadar air didasarkan pada perbedaan berat sampel sebelum dan sesudah dikeringkan, mengacu pada metode (AOAC 1995). Cawan porselin yang akan digunakan, dikeringkan terlebih dahulu kira-kira 1 jam pada suhu $105^{\circ} \mathrm{C}$, lalu didinginkan dalam desikator selama 30 menit dan ditimbang hingga beratnya konstan (A). Sampel ditimbang $2 \mathrm{~g}$ (B) dalam cawan, dikeringkan dalam oven pada suhu $100-105^{\circ} \mathrm{C}$ selama 5 jam atau beratnya konstan. Cawan yang berisi sampel didinginkan di dalam desikator selama 30 menit lalu ditimbang hingga beratnya tetap (C). Kadar air dihitung dengan rumus:

Kadar Air $\%=\begin{gathered}(A+B)-C \\ (B)\end{gathered} \quad x 100 \%$

Kadar Abu

Kadar abu dihitung dengan cara menimbang sisa mineral sebagai hasil pembakaran bahan organik pada suhu sekitar $550^{\circ} \mathrm{C}$, mengacu pada metode (AOAC 1995). Cawan porselin dikeringkan di dalam oven selama satu jam pada suhu $105^{\circ} \mathrm{C}$, lalu didinginkan selama 30 menit di dalam desikator dan ditimbang hingga didapatkan berat tetap (A). Sampel sebanyak 2 g (B) dimasukkan kedalam cawan porselin dan dipijarkan di atas nyala api pembakar bunsen hingga tidak berasap lagi. Cawan berisi sampel dimasukkan kedalam tanur listrik (furnace) dengan suhu $650^{\circ} \mathrm{C}$ selama \pm 12 jam. Cawan berisi abu didinginkan selama 30 menit pada desikator, kemudian ditimbang hingga didapatkan berat tetap (C). Kadar abu dihitung menggunakan rumus:

$$
\text { Kadar } A b u \%=\frac{(A+B)-B}{(B)} \times 100 \%
$$

\section{Fiskositas}

Prosedur pengamatan fiskositas dilakukan dengan cara memanaskan larutan karaginan dengan konsentrasi $1,5 \%$ dalam bak air mendidih sambil diaduk merata sampai suhu mencapai $75^{\circ} \mathrm{C}$. Fiskositas diukur dengan Viscometer Brookfield, spindel dipanaskan pada suhu $75^{\circ} \mathrm{C}$ kemudian dipasang ke alat ukur viscometer Brookfield. Posisi spindel dalam larutan panas diatur sampai tepat, fiskometer dihidupkan dan suhu larutan diukur, ketika suhu larutan mencapai $75^{\circ} \mathrm{C}$ dan nilai fiskositas diketahui dengan pembacaan viskosimeter pada skala 1 sampai 100. Pembacaan dilakukan setelah satu menit putaran penuh 2 kali untuk spindel nomor 1 . 


\section{Kadar Sulfat}

Pengukuran kadar sulfat mengacu pada FMC Corp (1977). Prinsip pengukuran kadar sulfat adalah gugus sulfat yang telah ditimbang, dan dihidrolisis diendapkan sebagai $\mathrm{BaSO}_{4}$, perhitungan kadar sulfat adalah sebagai berikut:

$$
\text { Kadar Sulfat } \%=\frac{(P \times 0,4116)}{(\text { Berat Sampel })} \times 100 \%
$$

Keterangan : $0,4116=$ massa atom relatif $\mathrm{SO}_{4}$ dibagi dengan massa atom relatif $\mathrm{BaSO}_{2}$

$$
P=\text { berat endapan } \mathrm{BaSO}_{4}(\mathrm{~g}) \text {. }
$$

\section{Kekuatan Gel}

Larutan karaginan $1,6 \%$ dan $\mathrm{KCl} 0,16 \%$ dipanaskan dalam bak air mendidih dengan pengadukan secara teratur sampai suhu $80^{\circ} \mathrm{C}$. Volume larutan dibuat sekitar $50 \mathrm{~mL}$, kemudian dimasukkan ke dalam cetakan gelas dan dibiarkan pada suhu $10^{\circ} \mathrm{C}$ selama 2 jam. Kekuatan gel diukur menggunakan alat TA.XT Texture Analyzer. Diameter probe yang digunakan adalah 0,5 inch atau $1,27 \mathrm{~cm}$, bobot probe sebesar 7,0790 g dan jarak penetrasi probe dengan gel adalam $20 \mathrm{~mm}$.

Kekuatan gel dapat didefinisikan sebagai massa (dalam gram) yang dibutuhkan untuk memasukkan probe ke dalam gel. Nilai kekuatan gel (breaking force) ditunjukkan oleh peak (puncak) pertama terjadi penurunan yang signifikan saat probe berpenetrasi ke dalam gel. Kekuatan gel pada alat ini diukur dalam satuan $g$ force, untuk konversi dalam satuan $\left(\mathrm{g} / \mathrm{cm}^{2}\right)$ perhitungan kekuatan gel menggunakan rumus:

$$
\text { Kekuatan gel }\left(\mathrm{g} / \mathrm{cm}^{2}\right)=
$$

$$
=\frac{\text { Tinggi kurva }(\mathrm{g} \text { force })}{\text { Luas permukaan kontak area probe }} \mathrm{x} \text { nilai kalibrasi }
$$

Nilai kalibrasi $=\frac{\text { bobot probe }(\mathrm{g})}{\text { jarak probe dengan gel }(\mathrm{cm})}$

\section{Analisis Data}

Penelitian dilakukan secara deskriptif, data hasil pengamatan penelitian diolah menggunakan Exel, merupakan rata-rata dari rendemen, kekuatan gel, viskositas, kadar air, kadar abu dan kadar sulfat

\section{HASIL DAN PEMBAHASAN}

Sifat fisiko kimia SRC dari rumput laut E. cottonii yang berasal dari Desa Waiheru Kota Ambon dan Desa Lermatang Kabupaten Maluku Tenggara Barat dapat dilihat pada Tabel 1. Hasil pengamatan menunjukkan bahwa terdapat perbedaan sifat fisiko kimia SRC yang dihasilkan oleh rumput laut dari kedua desa tersebut.

Rendemen SRC dari Desa Waiheru yaitu $27,3 \%$ lebih tinggi dari rendemen SRC Desa

Tabel 1 Parameter kualitas SRC E. cottonii

(Table 1 Quality Parameters of Semi Refined Carrageenan E. cottonii)

\begin{tabular}{ccc}
\hline Karakterisasi fisika-kimia/Physico- & \multicolumn{2}{c}{ Lokasi pengambilan/Location of seaweed } \\
\cline { 2 - 3 } Chemical Properties & Waiheru & Lermatang \\
\hline Rendemen/Yield (\%) & $27.3 \pm 0.60$ & $26.8 \pm 0.08$ \\
Kadar air/Mouisture content (\%) & $15.79 \pm 0.06$ & $16.04 \pm 0.15$ \\
Kadar abu/Ash content (\%) & $15.26 \pm 0.22$ & $21.24 \pm 0.06$ \\
Kadar sulfat/Sulfate content (\%) & $13.27 \pm 0.12$ & $12.34 \pm 0.06$ \\
Kekuatan gel/gel strength $\left(\mathrm{gr} / \mathrm{cm}^{2}\right)$ & $700.00 \pm 81.65$ & $100.00 \pm 70.71$ \\
Kekentalan/Fiscosity $(\mathrm{cP})$ & $121.60 \pm 0.16$ & $60.80 \pm 0.10$ \\
\hline
\end{tabular}


Lermatang yaitu $26,8 \%$. Perbedaan persentase rendemen SRC sangat dipengaruhi oleh lokasi budidaya rumput laut dilakukan (Fitri 2013). Rendemen SRC juga dipengaruhi oleh bahan pengekstrak, bahan pengekstrak yang digunakan pada penelitian ini adalah $\mathrm{KOH}$. Rendemen SRC hasil penelitian ini lebih rendah dari hasil penelitian Mishra et al. (2006) yang di ekstraksi menggunakan $\mathrm{KOH}$ dan presipitasi dengan metanol yaitu 62,4\%, namun nilai fiskositas lebih rendah dari hasil penelitian ini yaitu 24,21 cps. Rendemen SRC terbaik dihasilkan pada lokasi Waiheru, namun kedua hasil masih sesuai dengan standar ekspor rumput laut, berdasarkan Departemen Perdagangan standar yang ditetapkan minimum sebesar $25 \%$.

Kadar air dari SRC dari Waiheru yaitu 15,79\% dan Desa dari Lermatang 16,04\%. Kadar air SRC dari Desa Waiheru cenderung lebih rendah dibandingkan dengan SRC dari Desa Lermatang. Kadar air sangat dipengaruhi oleh cuaca saat penjemuran. Kadar air merupakan parameter yang dijadikan standar mutu oleh FAO (2014). Kadar air maksimal yang diperbolehkan adalah $12 \%$, berdasarkan standar tersebut maka SRC yang dihasilkan dari kedua lokasi melebihi standar yang telah ditentukan oleh FAO, sehingga harus diproses lebih lanjut dengan penjemuran ulang, namun apabila kadar air masih belum dapat tercapai maka perlu dicari metode pengeringan yang cocok.

Kadar abu SRC Desa Waiheru yaitu 15,26\% dan Desa Lermatang 21,24\%, kadar abu pada sampel bersumber dari pengotor ataupun garam yang masih terkandung dalam SRC. Kadar abu SRC dari desa Waiheru cenderung lebih rendah dari desa Lermatang, hal tersebut diduga disebabkan pencucian yang lebih baik terhadap rumput laut oleh nelayan. Kadar abu sebenarnya masih dalam ambang batas standar yang di tetapkan menurut FAO dan EEC yaitu maksimal 40\%, maka kadar abu SRC dapat diterima. Sedayu et al. (2008) melaporkan bahwa kadar abu SRC berkisar antara 18,5-16,73\%.

Fiskositas merupakan faktor kualitas yang penting untuk zat cair dan semi cair (kental) atau produk murni, untuk mengetahui kualitas dari produk akhir. Tujuan pengujian fiskositas adalah untuk mengetahui tingkat kekentalan SRC hasil ekstraksi (Raharjo 2009). Fiskositas SRC yang berasal dari Desa Waiheru yaitu 121,60 cP dan Desa Lermatang $60,80 \mathrm{cP}$ menurut $\mathrm{FAO}$, syarat mutu nilai fiskositas minimal $5 \mathrm{cP}$, sehingga kedua SRC masih berada dalam standar viskositas yang telah ditetapkan FAO. SRC dari desa Waiheru cenderung memiliki nilai fiskositas yang lebih tinggi dibandingkan dari desa Lermatang. Nilai fiskositas SRC dipengaruhi oleh konsentrasi $\mathrm{KOH}$ pada proses ekstraksi, nilai fiskositas menurun dengan semakin meningkatnyakonsentrasi $\mathrm{KOH}$,nilaifiskositas dilaporkan berkisar antara 13,62-49,95 cP (Moses et al. 2015). Fiskositas SRC berpengaruh terhadap pembentukan gel, fiskositas SRC yang rendah akan menghasilkan kekuatan gel yang rendah. Fiskositas suatu hidrokoloid dipengaruhi oleh beberapa faktor yaitu konsentrasi karaginan, temperatur, jenis karaginan, berat molekul dan adanya molekul-molekul lain (Towle 1973). Nilai kekentalan SRC meningkat dengan semakin banyak jumlah pencucian terhadap rumput laut setelah perebusan dalam $\mathrm{KOH}$, nilai kekentalan terendah pada perlakuan tanpa pencucian sebesar 49 cPs dan tertinggi pada pencucian sebanyak 3 kali sebesar 74 cPs (Sedayu et al. 2008). Fiskositas larutan karaginan ditentukan oleh sifat karaginan sebagai polielektrolit. Gaya tolakan (repulsion) antar muatan-muatan negatif sepanjang rantai polimer yaitu gugus sulfat, mengakibatkan rantai molekul menegang. Polimer tersebut dikelilingi oleh molekul molekul air yang terimobilisasi karena sifat hidrofiliknya, sehingga menyebabkan larutan karaginan bersifat kental (Guiseley et al. 1980). Nilai fiskositas SRC yang dihasilkan pada penelitian ini lebih besar bila dibandingkan dengan nilai fiskositas kappa karaginan komersial yang dilaporkan oleh Sandria et al. (2017) yaitu $34,46 \pm 0,51 \mathrm{cP}$.

Kadar sulfat SRC yang berasal dari desa Waiheru yaitu 13,27\% dan Desa Lermatang $12,34 \%$. SRC dari desa Lermatang mempunyai persentase kadar sulfat yang cenderung lebih rendah dibandingkan dengan desa Waiheru. Kadar sulfat pada penelitian ini lebih rendah 
dari standar SRC yang ditetapkan oleh FAO (2014), yaitu berkisar 15-40\% sedangkan hasil penelitian Sedayuetal. (2008) melaporkan kadar sulfat SRC yang dihasilkan dari masingmasing perlakuan adalah bervariasi berkisar antara $15,37-15,50 \%$.

Kekuatan gel merupakan salah satu parameter karateristik mutu karaginan dari rumput laut E. cottonii. Kekuatan gel SRC dari Desa Waiheru yaitu $700 \mathrm{~g} / \mathrm{cm}^{2}$ dan Desa Lermatan $100 \mathrm{~g} / \mathrm{cm}$ dan SRC dari kedua lokasi budidaya ini mempunyai kekutan gel yang memenuhi spesifikasi oleh BSN (2009) yaitu 20-500 g/cm2, kekuatan gel SRC dari Desa Waiheru cenderung lebih tinggi dibandingkan Desa Lermatan. Kadar garam yang tinggi pada rumput laut akan berpengaruh terhadap kekuatan gel, rumput laut yang kadar garamnya tinggi memiliki kandungan gel yang lebih rendah, karena kekuatan dalam mengikat jeli sanggat kurang disebabkan oleh adanya garam. Konsistensi gel dipengaruhi beberapa faktor antara lain jenis dan tipe karaginan dan juga adanya ion-ion serta pelarut yang menghambat pembentukan hidrokoloid (Towle 1973). Kekuatan gel kappa karaginan meningkat seiring dengan meningkatnya konsentrasi kation $\mathrm{K}^{+}$dan $\mathrm{Ca}^{2+}$ ketika garam klorida ditambahkan (Iglauer et al. 2011; Necas dan Bartosikova 2013). Sifat pembentukan gel karaginan berguna secara luas dalam makanan berbasis air dan susu.

\section{KESIMPULAN}

Hasil rendemen, kekuatan gel, fiskositas, kadar air, abu, sulfat SRC terbaik adalah dari Desa Waiheru Kota Ambon, namun secara keseluruhan SRC dari kedua lokasi ini memenuhi standar mutu karaginan FAO dan BSN. Parameter kadar air untuk 2 lokasi perlu mendapat perhatian untuk diteliti ulang, agar hasil SRC lebih baik lagi.

\section{UCAPAN TERIMA KASIH}

Penulis mengucapkan terima kasih kepada Direktorat Riset dan Pengabdian Kepada Masyarakat DIKTI atas pendanaan penelitian ini melalui MP3EI.

\section{DAFTAR PUSTAKA}

[AOAC] Association of Analytical Chemist
Publisher. 1995. Official Methods of Analysis $16^{\text {th }}$ Ed. Washington DC (AS): Association of Official Analitycal Chemist. Inc.Bindu MS, Levine IA. 2011. The commercial red seaweeds Kappaphycus alvareziian overview on farming and environment. Journal of Applied Phycology. 23(4): 789-796.

Bono A. Farm YY, Yasir SM, Arifin B, Jasni MN. 2011. Production of fresh seaweed powder using spray drying technique. Journal of Applied Sciences. 11(13): 23402345.

[BSN] Badan Standardisasi Nasional. 2009. Rumput laut kering. SNI 2690.1:2009. Jakarta (ID): Badan Standardisasi Nasional.

Campo VL, Kawano DF, Dilson BSJ, Carvalho I. 2009. Carrageenans: Biological properties, chemical modifications and structural analysis-a review. Carbohydrate Polymers. 77: 167-180.

Dewi EN, Darmanto YS, Ambariyanto. 2012. Characterization and quality of semi refined carrageenan (SRC) products from different Coastal Waters Based on fourier transform infrared technique. Journal of Coastal Development. 16(1): 25-31.

Dewi EN, Ibrahim R, Suharto S. 2015. Morphological structure characteristic and quality of semi refined carrageenan processed by different drying methods. Procedia Environmental Sciences. 23: 116-122.

[FAO] Food and Agriculture Organization. 2014. FAO JECFA Monographs 16. Specifications: Carrageenan. Diunduh pada : www.fao.org/3/a-i4144e.pdf

[FDA] Food and Drug Administration. 2017. Code of Federal Regulations Title 21. Sec. 172.620 Carrageenan. Diunduh pada: https://www.accessdata.fda.gov/scripts/ $c d r h / c f d o c s / c f c f r / c f r s e a r c h . c f m ? f r=172.620$

Fitri M. 2013. Kajian sifat fisika-kimia karaginan dari rumput laut jenis Eucheuma sp. di Perairan Sulawesi Selatan. Jurnal Galung Tropika. 2(2): 6476 .

FMC Corp. 1977. Carrageenan. Marine Colloid Monograph Number One. Marine Colloids Division FMC Corporation. New Jersey 
(USA): Springfield.

Guiseley KB, Stanley NF, White House PA. 1980. Carrageenan. Di dalam Davis $R L$ (Ed.) Handbook of Water Soluble Gums and Resins. London (NY): Toronto, Mc Graw Hill Book Company.

Iglauer S, Wu Y, Schuler P, Tang Y. 2011. Goddard III WA. Dilute iota- and Kappa Carrageenan Solutions with High Viscosities in High Salinity Brines. Journal of Petroleum Science and Engineering. 75: 304-311.

Mishra PC, Jayasankar R, Seema C. 2006. Yield and quality of carrageenan from Kappaphycus alvarezii subjected to different physical and chemical treatments. Seaweeds Research and Utilization. 28 (1): 113-117.

Moses J, Anandhakumar R, Shanmugam M. 2015. Effect of alkaline treatment on thesulfate content and quality of semirefined carrageenan prepared from seaweed Kappaphycus alvarezii Doty (Doty) farmed in Indian waters. African Journal of Biotechnology. 14(18): 15841589.

MustaphaS, ChandarH, AbidinZZ, Saghravani R, Harun MY. 2011. Production of semi refined carrageenan from Eucheuma cotonii. Journal of Scientific and Industrial Research. 70: 865-870.
Necas J, Bartosikova L, 2013. Carrageenan: A Review. Veterinarni Medicina. 58(4): 187-205.

Raharjo S. 2009. Budidaya dan pengolahan rumput laut. Jakarta (ID): Agromedia Pustaka.

Sandria N, Uju, Suptijah P. 2017. Depolimerisasi kappa karaginan dengan menggunakan peracetic acid. Jurnal Pengolahan Hasil Perikanan Indonesia. 20(3): 524-535.

Sedayu BB, Basmal J, Utomo BSB. 2008. Optimalisasi penggunaan air pada proses pembuatan semi-refined carrageenan (SRC). Jurnal Pascapanen dan Bioteknologi Kelautan dan Perikanan. 3(2): 183-191.

Towle 1973. Carrageenan. In Whisler RL (ed.). Industrial Gums: Polysaccharides and their Derivative. New York (AS): Academic Press.

Wenno MR, Thenu JL, Lopulalan CGC. 2012. Karakteristik kappa karaginan dari Kappaphycus alvarezii pada berbagai umur panen. Jurnal Pascapanen dan Bioteknologi Kelautan dan Perikanan. 7(1): 61-67.

Yong WTL, Chin JYY, Thien VY, Yasir S. 2014. Evaluation of growth rate and semi-refined carrageenan properties of tissue-cultured Kappaphycus alvarezii (Rhodophyta, Gigartinales). Phycological 